\title{
Woolly hair
}

INSERM

\section{Source}

INSERM. (1999). Orphanet: an online rare disease and orphan drug data base. Woolly hair. ORPHA:170

Woolly hair is a rare congenital abnormality of the structure of the scalp hair marked by extreme kinkiness of the hair. 